\title{
Cytokines and T Helper Cells in Diabetic Nephropathy Pathogenesis
}

\section{Liliane Silvano Araújo', Marcos Vinícius da Silva², Crislaine Aparecida da Silva1, Maria Luiza Reis Monteiro', Lívia Helena de Morais Pereira', Laura Penna Rocha1, Rosana Rosa Miranda Corrêa ${ }^{1}$, Marlene Antônia Reis ${ }^{1}$, Juliana Reis Machado ${ }^{1,3 *}$}

\author{
${ }^{1}$ General Pathology and Nephropathology Service, Institute of Biological and Natural Sciences of Federal University \\ of Triangulo Mineiro, Uberaba, Brazil \\ ${ }^{2}$ Immunology, Institute of Biological and Natural Sciences of Federal University of Triangulo Mineiro, \\ Uberaba, Brazil \\ ${ }^{3}$ General Pathology, Institute of Tropical Pathology and Public Health of Federal University of Goiás, \\ Goiânia, Brazil \\ Email: lili_silvano@yahoo.com.br,marcosuftm@gmail.com, crislaine.0604@gmail.com, marialuizapatologia@gmail.com, \\ liviahmp@hotmail.com, laurapenna1@hotmail.com, rosana@patge.uftm.edu.br, \\ mareispatologia@gmail.com, *juliana.patologiageral@gmail.com
}

How to cite this paper: Araújo, L.S., da Silva, M.V., da Silva, C.A., Monteiro, M.L.R., de Morais Pereira, L.H., Rocha, L.P., Corrêa, R.R.M., Reis, M.A. and Machado, J.R. (2016) Cytokines and T Helper Cells in Diabetic Nephropathy Pathogenesis. Journal of Diabetes Mellitus, 6, 230-246.

http://dx.doi.org/10.4236/jdm.2016.64025

Received: August 9, 2016

Accepted: September 11, 2016

Published: September 14, 2016

Copyright $\odot 2016$ by authors and Scientific Research Publishing Inc. This work is licensed under the Creative Commons Attribution International License (CC BY 4.0).

http://creativecommons.org/licenses/by/4.0/ (c) (i) Open Access

\section{Abstract}

Diabetic Nephropathy (DN) is considered the main cause of end stage kidney disease around the world. However, its pathogenesis is not completely established. More than just a direct consequence of chronic glycemic changes, recent studies had suggested Diabetic Nephropathy could be considered an inflammatory disease. It has been shown that concentrations of pro-inflammatory cytokines, as IL-1, IL-6, IL-18, IL-33, IFN- $\gamma$ and TNF- $\alpha$ actively participate in development and progression of DN, and thus, are involved in pathogenesis. Besides, changes in acquired immune response, especially the presence of cellular immune response profiles of pro-inflammatory and effector nature, mainly Th1 and Th17, as the imbalance between interaction of cytokines and $\mathrm{T}$ regulatory cells, foment the onset and progression of DN. Here we summarize the main evidences that support the critical role of the immune system in this condition. These new conceptual advances in DN understanding are essential for development of new the rapeutical strategies and prognostic factors, which could be protagonists or adjuvants to the current ones, leading ultimately to a better clinical management of $\mathrm{DN}$ patients.

\section{Keywords}

Diabetic Nephropathy, Cytokines, Cellular Immunity 


\section{Introduction}

Diabetic Nephropathy (DN) is the main cause of end stage renal disease (ESRD) in the world and reaches around 30\% of diabetic patients. Besides, it contributes to the risk of developing cardiovascular diseases which progressively increase as DN evolves, and most of these patients die due to these events [1]. DN affects around $35 \%$ of people with Diabetes Mellitus type 1 (DM1) and 10\% to $40 \%$ of those with Diabetes Mellitus type 2 (DM2) [2]. In Brazilians with DM2, the cumulative incidence in 10 years was 31\% [3], similarly to 34\% in Finnish [4], 35\% in Israeli [5] and 31\% in UKPDS-United Kingdom Prospective Diabetes Study [6].

Morphological changes in DN are similar in patients with DM1 and with DM2 [7]. Functional changes occur in nephrons, especially in glomeruli, including hyperfiltration and hyperperfusion [8]. All cellular elements of the kidney as glomerular endothelium, mesangial cell, podocytes and tubular epithelium are potential targets for hyperglycemic injury [9]. Among the main morphological changes, there are diffuse and nodular glomerulosclerosis, glomerular basement membrane thickening, glomerular hypertrophy, mesangial cells expansion, foot process effacement and tubular interstitial fibrosis, resulting in progressive albuminuria, reduction of glomerular filtration rate and blood pressure elevation [10]-[13].

$\mathrm{DN}$ is characterized by extracellular matrix (ECM) excessive accumulation, especially collagen and fibronectin, thickening of all basement membranes, including the glomerular (GBM) and tubular (TBM) ones and mesangial matrix increase, which leads to diffuse and nodular glomerulosclerosis- "Kimmelstiel and Wilson nodules", interstitial fibrosis and foot process effacement [14] [15]. Therefore, fibrosis is the essential and most important characteristic in DN and inflammation seems to be the central trigger in the onset and progression of renal fibrosis [16].

While it was thought the main causes of injury in DN were related to metabolic and hemodynamic factors, in the last years, studies have emphasized increasing evidences on the critical role of inflammation and immunomodulation, both in pathogenesis and progression of DN. Therefore, nowadays it is considered an inflammatory disease [17][20]. As an example, plasma concentration of some inflammatory cytokines is increased in diabetic patients, being strong predictors of development of diabetic secondary changes, particularly DN [21]-[23]. DM2 by itself is associated with inflammation, but inflammation also contributes significantly to the development of DN [24]. Here we summarize recent advances in DN understanding demonstrating immune system protagonism and the balance between regulation and inflammation in the establishment and progression of this disease.

\section{Proinflammatory Cytokines and DN}

The role of inflammatory cytokines in DN pathogenesis was suggested for the first time in 1991 by Hasegawa and collaborators [25]. In that paper, authors demonstrated that peritoneal macrophages cultured with glomerular basement membrane of diabetic animals produced significantly higher quantities of inflammatory cytokines, as tumor ne- 
crosis factor-alpha (TNF- $\alpha$ ) and interleukin (IL) 1, compared with those cultured with glomerular basement membrane of normal animals.

In clinical studies, increased serum concentration of inflammatory markers has been found in DM1 and DM2 patients, which seems to predict the onset and progression of diabetic complications [26] [27]. It was demonstrated proinflammatory cytokines concentrations increase with DN progression [28] [29] and are independent related with albumin urinary excretion showing a direct association with clinical markers of glomerular and tubular-interstitial lesions [30]. Experimental studies with diabetic models demonstrated inhibiting the recruitment of inflammatory cells to the kidney is a protective factor in DN [31] [32].

All renal cells (endothelial, epithelial, mesangial and tubular) are also able to synthesize proinflammatory cytokines such as tumor necrosis factor alpha (TNF- $\alpha$ ), interleukin 1 (IL-1) and IL-6, and therefore these cytokines, acting in a paracrine or autocrine manner can induce a variety of effects in different renal structures with an important role in development and progression of many renal diseases including DN [33] [34]. It is now known that among the inflammatory cytokines, IL-1, IL-6, IL-18 and TNF- $\alpha$ are relevant for DN development, performing many actions potentially involved in the development of its complications [35].

In DN experimental models, were observed an increase in IL-1 renal expression, related to chemotactic factors and adhesion molecules expression [36] [37]. IL-1 improves the synthesis of intercellular adhesion molecule 1 (ICAM-1) and vascular cellular adhesion molecule-1 (VCAM-1) by glomerular endothelial cells and induces de novo synthesis and expression of ICAM-1 by glomerular mesangial cells and renal tubular epithelium. Besides, this cytokine induces transient expression of E-selectin by endothelial cells [38] [39] as is also involved in development of intraglomerular changes related to prostaglandins synthesis by mesangial cells [40] and is directly related to increase in vascular endothelial cells permeability [41].

Currently, IL-33 other interleukin belonging to IL1 family, has been studied. Initially defined as a proinflammatory cytokine, some studies suggest that it can be associated with immune responses involving $\mathrm{T}$ cells and $\mathrm{B}$ regulators, indicating that IL-33 has a complex feature [42] [43]. IL-33 role in DN is not well defined [44]. A study that evaluated serum levels of Th1 and Th2 cytokines in diabetic patients with and without DN observed that patients with no DN showed an increase in IFN- $\gamma$, IL-12, IL-4 and IL-13 and a reduction of IL-33, with the involvement of both Th1 and Th2 response. In contrast, patients with DN had a more evident Th1 profile characterized by increased IFN- $\gamma$, IL- 2 and IL-12 and decreased Th2 cytokines IL-33 and IL-13, indicating that DN can be characterized by an increase in Th1 associated with suppression of Th2 response. Furthermore, the higher were microalbuminuria levels and more severe insulin resistance, the lower were IL-33 levels, which can indicate a protective effect of IL-33 during the progression of DN [45].

Furthermore, in experimental studies in which diabetes was induced in rats by means of intraperitoneal injection of Streptozotocin, an increase of IL-33 was demonstrated in 
serum and/or in renal parenchyma of diabetic rats, and this increase was even more evident in diabetic rats with contrast-induced nephropathy. These studies suggest that IL-33 may be associated with the onset and progression of ND [46] [47]. In a clinical study in which serum levels of IL-33 were compared between healthy patients, diabetic patients without nephropathy and patients with DM associated with microalbuminuria, which indicates nephropathy, an increase in IL-33 was observed in diabetic patients with or without nephropathy when compared to healthy patients. However, there was no difference when diabetic patients with or without nephropathy were compared. The results of this study suggest that IL-33 cannot be used as a marker of renal injury [48]. These controversial data in the literature show that the exact role of IL-33 in DN remains unknown and therefore more clinical and experimental studies are needed.

Others studies have reported an increase in plasmatic and urinary IL-18 levels in DN patients comparing with control group and also presented a significantly positive correlation with albumin urinary excretion rate in patients with DN [49] [50]. IL-18 is a potent cytokine implicated in various actions, including release of interferon- $\gamma$ (IFN- $\gamma$ ) which stimulates expression of chemokines receptors in human mesangial cells [51], synthesis of others inflammatory molecules as IL- 1 and TNF- $\alpha$, increase of ICAM-1 and apoptotic process in endothelial cells [52]-[54].

IL-6 is a proinflammatory cytokine and an important mediator of cell proliferation, endothelial cell permeability and increase in matrix production [55]. IL-6 plasma levels are increased in DN patients comparing with diabetic patients without nephropathy [56]. Besides, immunohistochemistry by hybridization in human renal biopsies showed an increased expression of RNAm which codifies IL-6 in infiltrating cells in mesangium, interstitium and tubules which also show a positive relationship with the severity of mesangial expansion [57]. IL-6 has been also related with increased expression of fibronectin [58] and increase in GBM thickness [24]. DM2 patients had an increase in IL-6 production associated not only with DN, but also with GBM thickness, crucial and earlier injury of DN, being considered a strong marker of declining renal function [24].

TNF- $\alpha$ is produced primarily by monocytes, macrophages and T cells, but also intrinsically by kidney cells [59]. Many studies with DN patients have found high plasmatic and urinary TNF- $\alpha$ levels comparing with non-diabetic patients and these concentrations increased with DN progression. These findings show there is a strong relation between increased levels of this inflammatory cytokine and development and progression of renal lesion in DM [30] [60]. Results of a recent Brazilian study showed that patients with DM1 macroalbuminuria had urinary levels of TNF- $\alpha$ and IL-10 significantly higher compared to normoalbuminuric, microalbuminuric and healthy groups. Besides, it was shown that only urinary TNF- $\alpha$ was correlated with the presence and severity of macroalbuminuria, been suggested by researchers as a useful marker in assessing progression of nephropathy in DM1 patients [61].

\section{Cellular Immune Response and DN}

Among the cells involved in inflammatory process, it is believed that $\mathrm{T}$ cells play a key 
role in DN early renal damage, especially by presenting cytotoxic effects, and activating tissue macrophages [62]. The first contribution in this regard was pointed to be the increased accumulation of local $\mathrm{T}$ cells in diabetic experimental models, being observed an increase in CD4+ and CD8+ T lymphocytes in the interstitium and glomeruli of diabetic rats [63] [64]. One study with diabetic models induced by Streptozotocin (STZ) demonstrated that in a gap of one month, CD4+ were the predominant cells in diabetic kidney, however, in a total period of eight months, the number of CD8+ cells became significant. These data suggests the kidney damage process is initiated by Th profile cells but cytotoxic $\mathrm{T}$ cells also play a role in later stages of disease [65].

In general, both activation of immune response mediated by $\mathrm{T}$ cells and humoral response mediated by B cells, can participate in type $1 \mathrm{DM}$ pathogenesis [66] [67]. In a study with non-obese diabetic rats for evaluating cellular and humoral immune response in DN early phase, was observed that both $\mathrm{T}$ cells and B cells infiltrate glomeruli in this phase [63]. On the other hand, in DM2, considered a non-autoimmune disease, characterized by insulin resistance and/or relative insulin deficiency, not much is known about $\mathrm{T}$ cells role in its pathogenesis [68].

InDM1, an increase in $\mathrm{T}$ cells was shown in juxtaglomerular region leading to disorder in glomerular albumin excretion and decreased renal filtration. It was also demonstrated that systemic T lymphocytes, especially CD8+ T cells in circulation, are correlated with albuminuria [69]. A multiple regression analyzes showed a positive association between T CD8+ lymphocytes and albumin in patients with DM2 and that activation of these cells could be a systemic response. T cells can be activated by many metabolic and genetic pathways, and in DM2 can be activated by hemodynamic, environmental and metabolic changes [69].

Mensah-Brown et al., showed a $\mathrm{T}$ cell increase in glomeruli and interstitium of diabetic mice compared with nondiabetic ones [70]. Studies have demonstrated that DM1 patients presenting proteinuria have increased circulating $\mathrm{T}$ cells levels when comparing with non-proteinuric patients, and this accumulation is correlated with albumin urinary excretion rate [71] [72]. Similarly, a more recent study showed the amount of $\mathrm{CD} 4+\mathrm{T}$ cells in interstitium of DM2 patients correlates with proteinuria level in these patients [64].

Based on cytokines profile and effector function, $\mathrm{CD} 4+\mathrm{T}$ helper cells can be divided into subfamilies such as Th1, Th2, Th17, regulatory T (Treg) CD4+ CD25+ cells [73] [74]. Th1 cells mainly produce gamma interferon (IFN- $\gamma$ ) and TNF- $\alpha$ and express transcription factor T-box expressed in T cells (T-bet), induce delayed hypersensitivity reactions, activate macrophages and promote cell-mediated immune response [75]. In contrast, Th2 profile is characterized by production of IL-4, IL-5 and IL-13. IL-4 is the cytokine responsible for activating IL-5 and IL-13 expression, as well as transcription factor Gata-binding protein-3 (GATA-3) which regulates these cytokines expression. Furthermore, Th2 cells suppress the differentiation of cells with Th1 profile responses, induce immunoglobulin E (IgE) production and, consequently, contribute for humoral immunity [76] [77]. 
T cells differentiation for Th17 profile is given by TNF- $\beta$ and IL- 6 in these cells activation. These cytokines activate STAT-3, which increases expression of transcription factor receptor-related orphan receptor $\gamma$-t $(\mathrm{ROR} \gamma \mathrm{t})$ and these factors increase the production of IL-17, a proinflammatory cytokine [78]. T-regulatory cells are characterized by the presence of transcription factor forkhead box protein 3 (Foxp3) and act regulating proinflammatory immune response, being able to suppress effector activity of various $\mathrm{T}$ helper cells subtypes in order to avoid damage to host due to excessive inflammatory response [79] [80].

Recent studies indicate that not only the cell imbalance between Th1/Th2 but also between Th17/Tregcontribute to pathogenesis of some inflammatory/autoimmune diseases, as rheumatoid arthritis [81], acute coronary syndrome [82], and diabetes type 1 and 2 [83] [84].

Studies indicate that increased levels of ICAM-1 and P-selectin in diabetic kidney combined with increase in IFN- $\gamma$ and migration inhibitory factor (MIF) levels, are associated with action of Th1 cells in glomeruli [85]. Little is known about mechanisms of action of Th1 cells in DM2 models for the development and progression of kidney disease. However, increased plasma levels of IFN- $\gamma$ and positive correlations between plasmatic IFN- $\gamma$, proteinuria and glomerular filtration rate were found in type 2 diabetic patients with declared nephropathy [86]. These results indicate that Th1 response together with proinflammatory cytokines could mediate tissue damage in patients with DN [86].

One study comparing patients with type $2 \mathrm{DN}$ and patients without nephropathy revealed no significant change in IL-4 plasma level [86]. Th17 cells produce IL-17A, IL-17F, TNF- $\alpha$ and IL-6, and induce inflammation in auto-immune diseases pathogenesis [77]. Studies have related the presence of Th17 cells in murine and human model of DM1 demonstrating their association in pathogenesis of type 1 diabetes [87]-[89]. It was showed that $\mathrm{T}$ cells from patients with DM2 have been diverted to exert a proinflammatory phenotype, thus requiring monocytes for maintenance and consequently promoting chronic inflammation by increasing IFN- $\gamma$ and IL-17 [90].

Recently, the role of IL-17 isoforms in DN has been investigated [91]. A study that evaluated the role of isoform IL-17A in DN observed that diabetic patients with advanced DN showed decreased serum and urinary levels of IL-17A and that DM1 animals with genetic deficiency of IL-17A developed more severe nephropathy. In DM1 and DM2 animals receiving low dose of IL-17A, DN onset was prevented, as well as an attenuation of established DN in those animals with genetically diabetes. These results suggest beneficial effects of IL-17A low doses administration in DN treatment [92]. However, IL-17A cannot be definitely associated with DM2 nephrotic complications, as increased plasmatic levels of IL-17A have been found in patients without nephropathy [93].

Treg cells (imunorregulators) exert important effects on immune homeostasis maintenance and immune tolerance by producing anti-inflammatory cytokines such as IL-10 and transforming growth factor- $\beta$ (TGF- $\beta$ ) [94]. Recently, was reported that im- 
balance of Th17/Th1/Tregs can contribute to development of type 2 diabetes and its complications [83]. Another previous study demonstrated Treg (CD4+ CD25+FoxP3+) cells could contribute for development and progression of DN in patients with DM2 [95]. Recently, was observed that Treg (CD4+FoxP3+) transfer in animal model resulted in decreased glomerular diameter and albuminuria. On the other hand, Treg cells depletion using monoclonal antibody anti-CD25 resulted in accelerating of DN symptoms progression with increased glomerular hyperfiltration and presence of albuminuria [96]. It has been demonstrated that in DM2 patients, the presence of Treg cells (CD4+ CD25+FoxP3+) is significantly reduced in patients with microalbuminuria comparing with control group, and the number of these cells in the kidney has an inverse correlation with albumin urinary excretion rate, thus suggesting that manipulation of the number or the function of Treg cells may be a strategy in order to reduce inflammation in DN [97]. However, the relation between Tregcells (CD4+ CD25+ FoxP3+) nd DN pathogenesis still requires further investigation [95].

Another anti-inflammatory cytokine produced by Treg cells is IL-35. Its role in type 1 diabetes is not well elucidated; however, a recent study reported an increase of Treg cells in DM1 mice (induced by multiple low doses of Streptozotocin). However, there was a decrease in production of anti-inflammatory cytokines (IL-10, IL-35, TGF- $\beta$ ) and an increase of proinflammatory cytokines (IFN-y, IL-2, IL-17) by these cells, indicating a phenotypic change of Treg cells in DM1 conditions. Furthermore, a reduction in serum levels of IL-35 in DM1 patients was observed compared with healthy control group. These results suggest that IL-35 decrease could be related to development of DM1 [98].

Regarding IL-10, initially described as an important cytokine of Th2 profile, with predominantly anti-inflammatory and immunosuppressive effects [99], it has been reported that the low capacity of production of this interleukin is associated with metabolic syndrome and DM2 [100]. In addition, other studies have shown elevated levels of IL-10 in the serum of patients with diabetic nephropathy, but also a positive correlation between IL-10 and albuminuria levels, thus suggesting a possible involvement of IL-10 in DN pathogenesis [101]-[103].

Recently, two new subfamilies of T effector cells, Th9 and Th22, have been identified [104]. The Th9 cells are characterized by production of IL-9 and IL-10 and are developed from naive CD $4+\mathrm{T}$ precursor cells in response to TGF- $\beta$ and IL-4 [87] [105] [106]. It was also shown that IL-9 secretion by murine Th2 cells was strongly dependent on TGF- $\beta$ and TGF- $\beta$ can redirect Th2 cells to a Th9 phenotype [105]. Besides, TGF- $\beta$ not only induces differentiation in anti-inflammatory Treg cells, but also in proinflammatory Th9, Th17 cells and inhibits Th22 differentiation [107]. A study with diabetic patients to determine whether the co-production of IL-9/IL-17 by CD4 cells is altered under inflammatory conditions, has shown that these subjects had more frequently memory CD4 cells with transitional capacity to produce IL-9 and IL-17. These data demonstrate the presence of IL-9+IL-17+ cells can play a role in autoimmune human diseases [108]. 
Another study evaluated serum levels of IL-9 and IL-17 in patients with diabetic kidney disease (DKD). It was suggested that there is a linear negative association between serum levels of IL-17 and DKD, whereas serum IL-9 levels were significantly reduced in diabetic group compared to the group DKD. IL-9 also showed a positive correlation with urea and microalbuminuria. These results suggest the involvement of these cytokines in the DKD, but more studies are needed to further elucidate their role [109].

Regarding Th22 cells, they produce IL-22 and differ from Th17 and Th1 cells due to their differentiation and function. They may be involved in pathology of inflammation, tumors and autoimmune diseases. However, until a few years ago, there were no data on Th22 cells in patients with DM1 [110] [111]. But recently, Xu and contributors conducted a study to identify and quantify different Th cells profiles by flow cytometry in DM1 patients in different phases. The study demonstrated changes in the amount of circulating Th1, Th17 and Th22 cells and data demonstrated that the increase of Th22 cells correlated with Th17 cells in patients with DM1, suggesting that Th22 cells may contribute to its pathogenesis [104]. In another study, it was also observed a link between Th22 and Th9 cells in DM1 patients. These patients showed an increase in Th9 and Th22 cells, as well as increased serum levels of IL-9 and IL-22 compared with healthy individuals [112].

\section{Conclusion}

Currently, DN has been considered an inflammatory disease with participation of both immune responses, innate and adaptive (humoral and cellular). Cells of immune system and various cytokines play important roles in complex pathogenesis of DN development and progression. These new conceptual advances in DN understanding can be crucial for the development of new therapeutic strategies and to determine prognostic, either protagonists or adjuvants to current ones, leading ultimately to a better clinical management of DN patients.

\section{Acknowledgements}

The authors appreciate the financial support of Conselho Nacional de Desenvolvimen to Científico e Tecnológico (CNPq), Coordenação de Aperfeiçoamento de Pessoal de Nível Superior (CAPES), Fundação de Amparo à Pesquisado Estado de Minas Gerais (FAPEMIG), and Fundação de Ensino e Pesquisa de Uberaba (FUNEPU).

\section{Conflict of Interests}

The authors declare no conflict of interests.

\section{References}

[1] Association, A.D. (2014) Standards of Medical Care in Diabetes: 2014. Diabetes Care, 37, S14-S80. http://dx.doi.org/10.2337/dc14-S014

[2] Andersen, A.R., Christiansen, J.S., Andersen, J.K., Kreiner, S. and Deckert, T. (1983) Di- 
abetic Nephropathy in Type 1 (Insulin-Dependent) Diabetes: An Epidemiological Study. Diabetologia, 25, 496-501. http://dx.doi.org/10.1007/BF00284458

[3] Murussi, M., Baglio, P., Gross, J.L. and Silveiro, S.P. (2002) Risk Factors for Microalbuminuria and Macroalbuminuria in Type 2 Diabetic Patients: A 9-Year Follow-Up Study. Diabetes Care, 25, 1101-1103. http://dx.doi.org/10.2337/diacare.25.6.1101

[4] Forsblom, C.M., Groop, P.H., Ekstrand, A., Tötterman, K.J., Sane, T., Saloranta, C. and Groop, L. (1998) Predictors of Progression from Normoalbuminuria to Microalbuminuria in NIDDM. Diabetes Care, 21, 1932-1938. http://dx.doi.org/10.2337/diacare.21.11.1932

[5] Ravid, M., Brosh, D., Ravid-Safran, D., Levy, Z. and Rachmani, R. (1998) Main Risk Factors for Nephropathy in Type 2 Diabetes Mellitus Are Plasma Cholesterol Levels, Mean Blood Pressure, and Hyperglycemia. Archives of Internal Medicine, 158, 998-1004.

http://dx.doi.org/10.1001/archinte.158.9.998

[6] Adler, A.I., Stevens, R.J., Manley, S.E., Bilous, R.W., Cull, C.A., Holman, R.R. and UKPDS Group (2003) Development and Progression of Nephropathy in Type 2 Diabetes: The United Kingdom Prospective Diabetes Study (UKPDS 64). Kidney International, 63, 225232. http://dx.doi.org/10.1046/j.1523-1755.2003.00712.x

[7] Hayashi, H., Karasawa, R., Inn, H., Saitou, T., Ueno, M., Nishi, S., Suzuki, Y., Ogino, S., Maruyama, Y. and Kouda, Y. (1992) An Electron Microscopic Study of Glomeruli in Japanese Patients with Non-Insulin Dependent Diabetes Mellitus. Kidney International, 41, 749-757. http://dx.doi.org/10.1038/ki.1992.117

[8] Dronavalli, S., Duka, I. and Bakris, G.L. (2008) The Pathogenesis of Diabetic Nephropathy. Nature Clinical Practice Endocrinology \& Metabolism, 4, 444-452. http://dx.doi.org/10.1038/ncpendmet0894

[9] Kanwar, Y.S., Wada, J., Sun, L., Xie, P., Wallner, E.I., Chen, S., Chugh, S. and Danesh, F.R. (2008) Diabetic Nephropathy: Mechanisms of Renal Disease Progression. Experimental Biology and Medicine (Maywood), 233, 4-11. http://dx.doi.org/10.3181/0705-MR-134

[10] Mauer, S.M., Steffes, M.W., Ellis, E.N., Sutherland, D.E., Brown, D.M. and Goetz, F.C. (1984) Structural-Functional Relationships in Diabetic Nephropathy. Journal of Clinical Investigation, 74, 1143-1155. http://dx.doi.org/10.1172/JCI111523

[11] Dalla Vestra, M., Saller, A., Bortoloso, E., Mauer, M. and Fioretto, P. (2000) Structural Involvement in Type 1 and Type 2 Diabetic Nephropathy. Diabetes \& Metabolism, 26, 8-14.

[12] Ziyadeh, F.N. (1993) The Extracellular Matrix in Diabetic Nephropathy. American Journal of Kidney Diseases, 22, 736-744. http://dx.doi.org/10.1016/S0272-6386(12)80440-9

[13] Mason, R.M. and Wahab, N.A. (2003) Extracellular Matrix Metabolism in Diabetic Nephropathy. Journal of the American Society of Nephrology, 14, 1358-1373. http://dx.doi.org/10.1097/01.ASN.0000065640.77499.D7

[14] Matheson, A., Willcox, M.D., Flanagan, J. and Walsh, B.J. (2010) Urinary Biomarkers Involved in Type 2 Diabetes: A Review. Diabetes/Metabolism Research and Reviews, 26, 150171. http://dx.doi.org/10.1002/dmrr.1068

[15] Ponchiardi, C., Mauer, M. and Najafian, B. (2013) Temporal Profile of Diabetic Nephropathy Pathologic Changes. Current Diabetes Reports, 13, 592-599. http://dx.doi.org/10.1007/s11892-013-0395-7

[16] Wada, J. and Makino, H. (2013) Inflammation and the Pathogenesis of Diabetic Nephropathy. Clinical Science, 124, 139-152. http://dx.doi.org/10.1042/CS20120198

[17] Rivero, A., Mora, C., Muros, M., García, J., Herrera, H. and Navarro-González, J.F. (2009) Pathogenic Perspectives for the Role of Inflammation in Diabetic Nephropathy. Clinical Science, 116, 479-492. http://dx.doi.org/10.1042/CS20080394 
[18] Navarro-González, J.F., Mora-Fernández, C., Muros de Fuentes, M. and García-Pérez, J. (2011) Inflammatory Molecules and Pathways in the Pathogenesis of Diabetic Nephropathy. Nature Reviews Nephrology, 7, 327-340. http://dx.doi.org/10.1038/nrneph.2011.51

[19] Hickey, F.B. and Martin, F. (2013) Diabetic Kidney Disease and Immune Modulation. Curr Current Opinion in Pharmacology, 13, 602-612. http://dx.doi.org/10.1016/j.coph.2013.05.002

[20] Barutta, F., Bruno, G., Grimaldi, S. and Gruden, G. (2014) Inflammation in Diabetic Nephropathy: Moving toward Clinical Biomarkers and Targets for Treatment. Endocrine, 48, 730-742. http://dx.doi.org/10.1007/s12020-014-0437-1

[21] Schmidt, M.I., Duncan, B.B., Sharrett, A.R., Lindberg, G., Savage, P.J., Offenbacher, S., Azambuja, M.I., Tracy, R.P. and Heiss, G. (1999) Markers of Inflammation and Prediction of Diabetes Mellitus in Adults (Atherosclerosis Risk in Communities Study): A Cohort Study. The Lancet, 353, 1649-1652. http://dx.doi.org/10.1016/S0140-6736(99)01046-6

[22] Pradhan, A.D., Manson, J.E., Rifai, N., Buring, J.E. and Ridker, P.M. (2001) C-Reactive Protein, Interleukin 6, and Risk of Developing Type 2 Diabetes Mellitus. JAMA, 286, 327-334. http://dx.doi.org/10.1001/jama.286.3.327

[23] Spranger, J., Kroke, A., Möhlig, M., Hoffmann, K., Bergmann, M.M., Ristow, M., Boeing, H. and Pfeiffer, A.F. (2003) Inflammatory Cytokines and the Risk to Develop Type 2 Diabetes: Results of the Prospective Population-Based European Prospective Investigation into Cancer and Nutrition (EPIC)-Potsdam Study. Diabetes, 52, 812-817. http://dx.doi.org/10.2337/diabetes.52.3.812

[24] Dalla Vestra, M., Mussap, M., Gallina, P., Bruseghin, M., Cernigoi, A.M., Saller, A., Plebani, M. and Fioretto, P. (2005) Acute-Phase Markers of Inflammation and Glomerular Structure in Patients with Type 2 Diabetes. Journal of the American Society of Nephrology, 16, S78-S82. http://dx.doi.org/10.1681/ASN.2004110961

[25] Hasegawa, G., Nakano, K., Sawada, M., Uno, K., Shibayama, Y., Ienaga, K. and Kondo, M. (1991) Possible Role of Tumor Necrosis Factor and Interleukin-1 in the Development of Diabetic Nephropathy. Kidney International, 40, 1007-1012. http://dx.doi.org/10.1038/ki.1991.308

[26] Harjutsalo, V. and Groop, P.H. (2014) Epidemiology and Risk Factors for Diabetic Kidney Disease. Advances in Chronic Kidney Disease, 21, 260-266. http://dx.doi.org/10.1053/j.ackd.2014.03.009

[27] Pickup, J.C., Chusney, G.D., Thomas, S.M. and Burt, D. (2000) Plasma Interleukin-6, Tumour Necrosis Factor Alpha and Blood Cytokine Production in Type 2 Diabetes. Life Sciences, 67, 291-300. http://dx.doi.org/10.1016/S0024-3205(00)00622-6

[28] Festa, A., D’Agostino, R., Howard, G., Mykkänen, L., Tracy, R.P. and Haffner, S.M. (2000) Inflammation and Microalbuminuria in Nondiabetic and Type 2 Diabetic Subjects: The Insulin Resistance Atherosclerosis Study. Kidney International, 58, 1703-1710. http://dx.doi.org/10.1046/j.1523-1755.2000.00331.x

[29] Bruno, G., Merletti, F., Biggeri, A., Bargero, G., Ferrero, S., Pagano, G., Cavallo Perin, P. and Study, C.M. (2003) Progression to Overt Nephropathy in Type 2 Diabetes: The Casale Monferrato Study. Diabetes Care, 26, 2150-2155. http://dx.doi.org/10.2337/diacare.26.7.2150

[30] Navarro, J.F., Mora, C., Maca, M. and Garca, J. (2003) Inflammatory Parameters Are Independently Associated with Urinary Albumin in Type 2 Diabetes Mellitus. American Journal of Kidney Diseases, 42, 53-61. http://dx.doi.org/10.1016/S0272-6386(03)00408-6

[31] Awad, A.S., Kinsey, G.R., Khutsishvili, K., Gao, T., Bolton, W.K. and Okusa, M.D. (2011) 
Monocyte/Macrophage Chemokine Receptor CCR2 Mediates Diabetic Renal Injury. American Journal of Physiology-Renal Physiology, 301, F1358-F1366.

http://dx.doi.org/10.1152/ajprenal.00332.2011

[32] Chow, F.Y., Nikolic-Paterson, D.J., Ozols, E., Atkins, R.C. and Tesch, G.H. (2005) Intercellular Adhesion Molecule-1 Deficiency Is Protective against Nephropathy in Type 2 Diabetic $\mathrm{db} / \mathrm{db}$ Mice. Journal of the American Society of Nephrology, 16, 1711-1722. http://dx.doi.org/10.1681/ASN.2004070612

[33] Ostendorf, T., Burg, M. and Floege, J. (1996) Cytokines and Glomerular Injury. Kidney and Blood Pressure Research, 19, 281-289. http://dx.doi.org/10.1159/000174088

[34] Noronha, I.L., Niemir, Z., Stein, H. and Waldherr, R. (1995) Cytokines and Growth Factors in Renal Disease. Nephrology Dialysis Transplantation, 10, 775-786.

[35] Navarro-González, J.F. and Mora-Fernández, C. (2008) The Role of Inflammatory Cytokines in Diabetic Nephropathy. Journal of the American Society of Nephrology, 19, 433442. http://dx.doi.org/10.1681/ASN.2007091048

[36] Sassy-Prigent, C., Heudes, D., Mandet, C., Bélair, M.F., Michel, O., Perdereau, B., Bariéty, J. and Bruneval, P. (2000) Early Glomerular Macrophage Recruitment in Streptozotocin-Induced Diabetic Rats. Diabetes, 49, 466-475. http://dx.doi.org/10.2337/diabetes.49.3.466

[37] Navarro, J.F., Milena, F.J., Mora, C., León, C. and García, J. (2006) Renal Pro-Inflammatory Cytokine Gene Expression in Diabetic Nephropathy: Effect of Angiotensin-Converting Enzyme Inhibition and Pentoxifylline Administration. American Journal of Nephrology, 26, 562-570. http://dx.doi.org/10.1159/000098004

[38] Brady, H.R. (1994) Leukocyte Adhesion Molecules and Kidney Diseases. Kidney International, 45, 1285-1300. http://dx.doi.org/10.1038/ki.1994.169

[39] Park, C.W., Kim, J.H., Lee, J.H., Kim, Y.S., Ahn, H.J., Shin, Y.S., Kim, S.Y., Choi, E.J., Chang, Y.S., Bang, B.K. and Lee, J.W. (2000) High Glucose-Induced Intercellular Adhesion Molecule-1 (ICAM-1) Expression through an Osmotic Effect in Rat Mesangial Cells Is PKC-NF- $\kappa$ B-Dependent. Diabetologia, 43, 1544-1553. http://dx.doi.org/10.1007/s001250051567

[40] Pfeilschifter, J., Pignat, W., Vosbeck, K. and Märki, F. (1989) Interleukin 1 and Tumor Necrosis Factor Synergistically Stimulate Prostaglandin Synthesis and Phospholipase A2 Release from Rat Renal Mesangial Cells. Biochemical and Biophysical Research Communications, 159, 385-394. http://dx.doi.org/10.1016/0006-291X(89)90003-X

[41] Royall, J.A., Berkow, R.L., Beckman, J.S., Cunningham, M.K., Matalon, S. and Freeman, B.A. (1989) Tumor Necrosis Factor and Interleukin 1 Alpha Increase Vascular Endothelial Permeability. American Journal of Physiology, 257, L399-L410.

[42] Schiering, C., Krausgruber, T., Chomka, A., Fröhlich, A., Adelmann, K., Wohlfert, E.A., Pott, J., Griseri, T., Bollrath, J., Hegazy, A.N., Harrison, O.J., Owens, B.M., Löhning, M., Belkaid, Y., Fallon, P.G. and Powrie, F. (2014) The Alarmin IL-33 Promotes Regulatory T-Cell Function in the Intestine. Nature, 513, 564-568. http://dx.doi.org/10.1038/nature13577

[43] Sattler, S., Ling, G.S., Xu, D., Hussaarts, L., Romaine, A., Zhao, H., Fossati-Jimack, L., Malik, T., Cook, H.T., Botto, M., Lau, Y.L., Smits, H.H., Liew, F.Y. and Huang, F.P. (2014) IL-10-Producing Regulatory B Cells Induced by IL-33 (Breg ${ }^{\mathrm{IL}-33}$ ) Effectively Attenuate Mucosal Inflammatory Responses in the Gut. Journal of Autoimmunity, 50, 107-122. http://dx.doi.org/10.1016/j.jaut.2014.01.032

[44] Schmitz, J., Owyang, A., Oldham, E., Song, Y., Murphy, E., McClanahan, T.K., Zurawski, G., Moshrefi, M., Qin, J., Li, X., Gorman, D.M., Bazan, J.F. and Kastelein, R.A. (2005) IL-33, 
an Interleukin-1-Like Cytokine That Signals via the IL-1 Receptor-Related Protein ST2 and Induces T Helper Type 2-Associated Cytokines. Immunity, 23, 479-490.

http://dx.doi.org/10.1016/j.immuni.2005.09.015

[45] Anand, G., Vasanthakumar, R., Mohan, V., Babu, S. and Aravindhan, V. (2014) Increased IL-12 and Decreased IL-33 Serum Levels Are Associated with Increased Th1 and Suppressed Th2 Cytokine Profile in Patients with Diabetic Nephropathy (CURES-134). International Journal of Clinical and Experimental Pathology, 7, 8008-8015.

[46] Demirtas, L., Turkmen, K., Kandemir, F.M., Ozkaraca, M., Kucukler, S., Gürbüzel, M. and Comakl1, S. (2016) The Possible Role of Interleukin-33 as a New Player in the Pathogenesis of Contrast-Induced Nephropathy in Diabetic Rats. Renal Failure, 38, 952-960. http://dx.doi.org/10.3109/0886022X.2016.1165034

[47] Onk, D., Onk, O.A., Turkmen, K., Erol, H.S., Ayazoglu, T.A., Keles, O.N., Halici, M. and Topal, E. (2016) Melatonin Attenuates Contrast-Induced Nephropathy in Diabetic Rats: The Role of Interleukin-33 and Oxidative Stress. Mediators of Inflammation, 2016, Article ID: 9050828.

[48] Caner, S., Usluoğulları, C.A., Balkan, F., Büyükcam, F., Kaya, C., Saçıkara, M., Koca, C., Ersoy, R. and Çakır, B. (2014) Is IL-33 Useful to Detect Early Stage of Renal Failure? Renal Failure, 36, 78-80. http://dx.doi.org/10.3109/0886022X.2013.832313

[49] Moriwaki, Y., Yamamoto, T., Shibutani, Y., Aoki, E., Tsutsumi, Z., Takahashi, S., Okamura, H., Koga, M., Fukuchi, M. and Hada, T. (2003) Elevated Levels of Interleukin-18 and Tumor Necrosis Factor-Alpha in Serum of Patients with Type 2 Diabetes Mellitus: Relationship with Diabetic Nephropathy. Metabolism, 52, 605-608.

http://dx.doi.org/10.1053/meta.2003.50096

[50] Nakamura, A., Shikata, K., Hiramatsu, M., Nakatou, T., Kitamura, T., Wada, J., Itoshima, T. and Makino, H. (2005) Serum Interleukin-18 Levels Are Associated with Nephropathy and Atherosclerosis in Japanese Patients with Type 2 Diabetes. Diabetes Care, 28, 28902895. http://dx.doi.org/10.2337/diacare.28.12.2890

[51] Uciechowski, P., Schwarz, M., Gessner, J.E., Schmidt, R.E., Resch, K. and Radeke, H.H. (1998) IFN- $\gamma$ Induces the High-Affinity Fc Receptor I for IgG (CD64) on Human Glomerular Mesangial Cells. European Journal of Immunology, 28, 2928-2935. http://dx.doi.org/10.1002/(SICI)1521-4141(199809)28:09<2928::AID-IMMU2928>3.0.CO;2 $\underline{-8}$

[52] Dai, S.M., Matsuno, H., Nakamura, H., Nishioka, K. and Yudoh, K. (2004) Interleukin-18 Enhances Monocyte Tumor Necrosis Factor $\alpha$ and Interleukin- $1 \beta$ Production Induced by Direct Contact with T Lymphocytes: Implications in Rheumatoid Arthritis. Arthritis \& Rheumatology, 50, 432-443. http://dx.doi.org/10.1002/art.20064

[53] Mariño, E. and Cardier, J.E. (2003) Differential Effect of IL-18 on Endothelial Cell Apoptosis Mediated by TNF- $\alpha$ and Fas (CD95). Cytokine, 22, 142-148. http://dx.doi.org/10.1016/S1043-4666(03)00150-9

[54] Stuyt, R.J., Netea, M.G., Geijtenbeek, T.B., Kullberg, B.J., Dinarello, C.A. and van der Meer, J.W. (2003) Selective Regulation of Intercellular Adhesion Molecule-1 Expression by Interleukin-18 and Interleukin-12 on Human Monocytes. Immunology, 110, 329-334. http://dx.doi.org/10.1046/j.1365-2567.2003.01747.x

[55] Forbes, J.M. and Cooper, M.E. (2013) Mechanisms of Diabetic Complications. Physiological Reviews, 93, 137-188. http://dx.doi.org/10.1152/physrev.00045.2011

[56] Mahadevan, P., Larkins, R.G., Fraser, J.R., Fosang, A.J. and Dunlop, M.E. (1995) Increased Hyaluronan Production in the Glomeruli from Diabetic Rats: A Link between Glucose-In- 
duced Prostaglandin Production and Reduced Sulphated Proteoglycan. Diabetologia, 38, 298-305. http://dx.doi.org/10.1007/BF00400634

[57] Suzuki, D., Miyazaki, M., Naka, R., Koji, T., Yagame, M., Jinde, K., Endoh, M., Nomoto, Y. and Sakai, H. (1995) In Situ Hybridization of Interleukin 6 in Diabetic Nephropathy. Diabetes, 44, 1233-1238. http://dx.doi.org/10.2337/diab.44.10.1233

[58] Coleman, D.L. and Ruef, C. (1992) Interleukin-6: An Autocrine Regulator of Mesangial Cell Growth. Kidney International, 41, 604-606. http://dx.doi.org/10.1038/ki.1992.91

[59] Dong, X., Swaminathan, S., Bachman, L.A., Croatt, A.J., Nath, K.A. and Griffin, M.D. (2007) Resident Dendritic Cells Are the Predominant TNF-Secreting Cell in Early Renal Ischemia-Reperfusion Injury. Kidney International, 71, 619-628. http://dx.doi.org/10.1038/sj.ki.5002132

[60] Navarro, J.F., Mora, C., Muros, M. and García, J. (2006) Urinary Tumour Necrosis Factor-Alpha Excretion Independently Correlates with Clinical Markers of Glomerular and Tubulointerstitial Injury in Type 2 Diabetic Patients. Nephrology Dialysis Transplantation, 21, 3428-3434. http://dx.doi.org/10.1093/ndt/gfl469

[61] Pestana, R.M., Domingueti, C.P., Duarte, R.C., Fóscolo, R.B., Reis, J.S., Rodrigues, A.M., Martins, L.B., Sousa, L.P., Lage, D.P., Ferreira, C.N., Ferreira, A.V., Fernandes, A.P. and Gomes, K.B. (2016) Cytokines Profile and Its Correlation with Endothelial Damage and Oxidative Stress in Patients with Type 1 Diabetes Mellitus and Nephropathy. Immunologic Research, 64, 951-960. http://dx.doi.org/10.1007/s12026-016-8806-x

[62] Nguyen, D.V., Shaw, L.C. and Grant, M.B. (2012) Inflammation in the Pathogenesis of Microvascular Complications in Diabetes. Frontiers in Endocrinology, 3, 170. http://dx.doi.org/10.3389/fendo.2012.00170

[63] Xiao, X., Ma, B., Dong, B., Zhao, P., Tai, N., Chen, L., Wong, F.S. and Wen, L. (2009) Cellular and Humoral Immune Responses in the Early Stages of Diabetic Nephropathy in NOD Mice. Journal of Autoimmunity, 32, 85-93. http://dx.doi.org/10.1016/j.jaut.2008.12.003

[64] Moon, J.Y., Jeong, K.H., Lee, T.W., Ihm, C.G., Lim, S.J. and Lee, S.H. (2012) Aberrant Recruitment and Activation of T Cells in Diabetic Nephropathy. American Journal of Nephrology, 35, 164-174. http://dx.doi.org/10.1159/000334928

[65] Lim, A.K., Ma, F.Y., Nikolic-Paterson, D.J., Kitching, A.R., Thomas, M.C. and Tesch, G.H. (2010) Lymphocytes Promote Albuminuria, but Not Renal Dysfunction or Histological Damage in a Mouse Model of Diabetic Renal Injury. Diabetologia, 53, 1772-1782. http://dx.doi.org/10.1007/s00125-010-1757-1

[66] van Belle, T.L., Coppieters, K.T. and von Herrath, M.G. (2011) Type 1 Diabetes: Etiology, Immunology, and Therapeutic Strategies. Physiological Reviews, 91, 79-118. http://dx.doi.org/10.1152/physrev.00003.2010

[67] Heurtier, A.H. and Boitard, C. (1997) T-Cell Regulation in Murine and Human Autoimmune Diabetes: The Role of TH1 and TH2 Cells. Diabetes \& Metabolism, 23, 377-385.

[68] Nikolajczyk, B.S., Jagannathan-Bogdan, M., Shin, H. and Gyurko, R. (2011) State of the Union between Metabolism and the Immune System in Type 2 Diabetes. Genes and Immunity, 12, 239-250. http://dx.doi.org/10.1038/gene.2011.14

[69] Lei, L., Mao, Y., Meng, D., Zhang, X., Cui, L., Huo, Y. and Wang, Y. (2014) Percentage of Circulating CD8+ T Lymphocytes Is Associated with Albuminuria in Type 2 Diabetes Mellitus. Experimental and Clinical Endocrinology \& Diabetes, 122, 27-30.

[70] Mensah-Brown, E.P., Obineche, E.N., Galadari, S., Chandranath, E., Shahin, A., Ahmed, I., Patel, S.M. and Adem, A. (2005) Streptozotocin-Induced Diabetic Nephropathy in Rats: 
The Role of Inflammatory Cytokines. Cytokine, 31, 180-190.

http://dx.doi.org/10.1016/j.cyto.2005.04.006

[71] Moriya, R., Manivel, J.C. and Mauer, M. (2004) Juxtaglomerular Apparatus T-Cell Infiltration Affects Glomerular Structure in Type 1 Diabetic Patients. Diabetologia, 47, 82-88.

http://dx.doi.org/10.1007/s00125-003-1253-y

[72] Bending, J.J., Lobo-Yeo, A., Vergani, D. and Viberti, G.C. (1988) Proteinuria and Activated T-Lymphocytes in Diabetic Nephropathy. Diabetes, 37, 507-511. http://dx.doi.org/10.2337/diab.37.5.507

[73] Abbas, A.K., Murphy, K.M. and Sher, A. (1996) Functional Diversity of Helper T Lymphocytes. Nature, 383, 787-793. http://dx.doi.org/10.1038/383787a0

[74] Mosmann, T.R. and Sad, S. (1996) The Expanding Universe of T-Cell Subsets: Th1, Th2 and More. Immunology Today, 17, 138-146.

http://dx.doi.org/10.1016/0167-5699(96)80606-2

[75] Mosmann, T.R., Cherwinski, H., Bond, M.W., Giedlin, M.A. and Coffman, R.L. (1986) Two Types of Murine Helper T Cell Clone. I. Definition According to Profiles of Lymphokine Activities and Secreted Proteins. The Journal of Immunology, 136, 2348-2357.

[76] Adkins, B., Leclerc, C. and Marshall-Clarke, S. (2004) Neonatal Adaptive Immunity Comes of Age. Nature Reviews Immunology, 4, 553-564. http://dx.doi.org/10.1038/nri1394

[77] Bettelli, E., Oukka, M. and Kuchroo, V.K. (2007) $\mathrm{T}_{\mathrm{H}}-17$ Cells in the Circle of Immunity and Autoimmunity. Nature Immunology, 8, 345-350. http://dx.doi.org/10.1038/ni0407-345

[78] Yang, X.P., Ghoreschi, K., Steward-Tharp, S.M., Rodriguez-Canales, J., Zhu, J., Grainger, J.R., Hirahara, K., Sun, H.W., Wei, L., Vahedi, G., Kanno, Y., O’Shea, J.J. and Laurence, A. (2011) Opposing Regulation of the Locus Encoding IL-17 through Direct, Reciprocal Actions of STAT3 and STAT5. Nature Immunology, 12, 247-254.

http://dx.doi.org/10.1038/ni.1995

[79] Josefowicz, S.Z., Lu, L.F. and Rudensky, A.Y. (2012) Regulatory T Cells: Mechanisms of Differentiation and Function. Annual Review of Immunology, 30, 531-564.

http://dx.doi.org/10.1146/annurev.immunol.25.022106.141623

[80] Nunes-Alves, C., Booty, M.G., Carpenter, S.M., Jayaraman, P., Rothchild, A.C. and Behar, S.M. (2014) In Search of a New Paradigm for Protective Immunity to TB. Nature Reviews Microbiology, 12, 289-299. http://dx.doi.org/10.1038/nrmicro3230

[81] Boissier, M.C., Assier, E., Falgarone, G. and Bessis, N. (2008) Shifting the Imbalance from Th1/Th2 to Th17/Treg: The Changing Rheumatoid Arthritis Paradigm. Joint Bone Spine, 75, 373-375. http://dx.doi.org/10.1016/j.jbspin.2008.04.005

[82] Cheng, X., Yu, X., Ding, Y.J., Fu, Q.Q., Xie, J.J., Tang, T.T., Yao, R., Chen, Y. and Liao, Y.H. (2008) The Th17/Treg Imbalance in Patients with Acute Coronary Syndrome. Clinical Immunology, 127, 89-97. http://dx.doi.org/10.1016/j.clim.2008.01.009

[83] Zeng, C., Shi, X., Zhang, B., Liu, H., Zhang, L., Ding, W. and Zhao, Y. (2012) The Imbalance of Th17/Th1/Tregs in Patients with Type 2 Diabetes: Relationship with Metabolic Factors and Complications. Journal of Molecular Medicine, 90, 175-186. http://dx.doi.org/10.1007/s00109-011-0816-5

[84] Ryba-Stanisławowska, M., Skrzypkowska, M., Myśliwiec, M. and Myśliwska, J. (2013) Loss of the Balance between CD4 $4^{+}$Foxp $3^{+}$Regulatory T Cells and CD4 ${ }^{+} \mathrm{IL} 17 \mathrm{~A}^{+}$Th17 Cells in Patients with Type 1 Diabetes. Human Immunology, 74, 701-707.

http://dx.doi.org/10.1016/j.humimm.2013.01.024

[85] Odobasic, D., Kitching, A.R., Tipping, P.G. and Holdsworth, S.R. (2005) CD80 and CD86 Costimulatory Molecules Regulate Crescentic Glomerulonephritis by Different Mechan- 
isms. Kidney International, 68, 584-594. http://dx.doi.org/10.1111/j.1523-1755.2005.00436.x

[86] Wu, C.C., Chen, J.S., Lu, K.C., Chen, C.C., Lin, S.H., Chu, P., Sytwu, H.K. and Lin, Y.F. (2010) Aberrant Cytokines/Chemokines Production Correlate with Proteinuria in Patients with Overt Diabetic Nephropathy. Clinica Chimica Acta, 411, 700-704.

http://dx.doi.org/10.1016/j.cca.2010.01.036

[87] Bending, D., De la Peña, H., Veldhoen, M., Phillips, J.M., Uyttenhove, C., Stockinger, B. and Cooke, A. (2009) Highly Purified Th17 Cells from BDC2.5NOD Mice Convert into Th1-Like Cells in NOD/SCID Recipient Mice. Journal of Clinical Investigation, 119, 565572. http://dx.doi.org/10.1172/JCI37865

[88] Bradshaw, E.M., Raddassi, K., Elyaman, W., Orban, T., Gottlieb, P.A., Kent, S.C. and Hafler, D.A. (2009) Monocytes from Patients with Type 1 Diabetes Spontaneously Secrete Proinflammatory Cytokines Inducing Th17 Cells. The Journal of Immunology, 183, 44324439. http://dx.doi.org/10.4049/jimmunol.0900576

[89] Honkanen, J., Nieminen, J.K., Gao, R., Luopajarvi, K., Salo, H.M., Ilonen, J., Knip, M., Otonkoski, T. and Vaarala, O. (2010) IL-17 Immunity in Human Type 1 Diabetes. The Journal of Immunology, 185, 1959-1967. http://dx.doi.org/10.4049/jimmunol.1000788

[90] Jagannathan-Bogdan, M., McDonnell, M.E., Shin, H., Rehman, Q., Hasturk, H., Apovian, C.M. and Nikolajczyk, B.S. (2011) Elevated Proinflammatory Cytokine Production by a Skewed T Cell Compartment Requires Monocytes and Promotes Inflammation in Type 2 Diabetes. The Journal of Immunology, 186, 1162-1172.

http://dx.doi.org/10.4049/jimmunol.1002615

[91] Galvan, D.L. and Danesh, F.R. (2016) Paradoxical Role of IL-17 in Progression of Diabetic Nephropathy. Journal of the American Society of Nephrology, 27, 657-658. http://dx.doi.org/10.1681/ASN.2015070813

[92] Mohamed, R., Jayakumar, C., Chen, F., Fulton, D., Stepp, D., Gansevoort, R.T. and Ramesh, G. (2016) Low-Dose IL-17 Therapy Prevents and Reverses Diabetic Nephropathy, Metabolic Syndrome, and Associated Organ Fibrosis. Journal of the American Society of Nephrology, 27, 745-765. http://dx.doi.org/10.1681/ASN.2014111136

[93] Arababadi, M.K., Nosratabadi, R., Hassanshahi, G., Yaghini, N., Pooladvand, V., Shamsizadeh, A., Hakimi, H. and Derakhshan, R. (2010) Nephropathic Complication of Type-2 Diabetes Is Following Pattern of Autoimmune Diseases? Diabetes Research and Clinical Practice, 87, 33-37. http://dx.doi.org/10.1016/j.diabres.2009.09.027

[94] Sakaguchi, S., Ono, M., Setoguchi, R., Yagi, H., Hori, S., Fehervari, Z., Shimizu, J., Takahashi, T. and Nomura, T. (2006) Foxp $3^{+} \mathrm{CD} 25^{+} \mathrm{CD} 4^{+}$Natural Regulatory T Cells in Dominant Self-Tolerance and Autoimmune Disease. Immunological Reviews, 212, 8-27. http://dx.doi.org/10.1111/j.0105-2896.2006.00427.x

[95] Xu, J., Su, H.L., Wang, J.H. and Zhang, C.H. (2009) [Role of CD4 ${ }^{+}$CD25 $5^{+}$Foxp3 ${ }^{+}$Regulatory T Cells in Type 2 Diabetic Nephropathy]. Journal of Southern Medical University, 29, 137 139.

[96] Eller, K., Kirsch, A., Wolf, A.M., Sopper, S., Tagwerker, A., Stanzl, U., Wolf, D., Patsch, W., Rosenkranz, A.R. and Eller, P. (2011) Potential Role of Regulatory T Cells in Reversing Obesity-Linked Insulin Resistance and Diabetic Nephropathy. Diabetes, 60, 2954-2962. http://dx.doi.org/10.2337/db11-0358

[97] Wu, C.C., Sytwu, H.K., Lu, K.C. and Lin, Y.F. (2011) Role of T Cells in Type 2 Diabetic Nephropathy. Experimental Diabetes Research, 2011, Article ID: 514738.

[98] Singh, K., Kadesjö, E., Lindroos, J., Hjort, M., Lundberg, M., Espes, D., Carlsson, P.O., Sandler, S. and Thorvaldson, L. (2015) Interleukin-35 Administration Counteracts Estab- 
lished Murine Type 1 Diabetes-Possible Involvement of Regulatory T Cells. Scientific Reports, 5, Article No. 12633. http://dx.doi.org/10.1038/srep12633

[99] Lalani, I., Bhol, K. and Ahmed, A.R. (1997) Interleukin-10: Biology, Role in Inflammation and Autoimmunity. Annals of Allergy, Asthma \& Immunology, 79, 469-484.

http://dx.doi.org/10.1016/S1081-1206(10)63052-9

[100] van Exel, E., Gussekloo, J., de Craen, A.J., Frölich, M., Bootsma-Van Der Wiel, A., Westendorp, R.G. and Study, L.P. (2002) Low Production Capacity of Interleukin-10 Associates with the Metabolic Syndrome and Type 2 Diabetes : The Leiden 85-Plus Study. Diabetes, 51, 1088-1092. http://dx.doi.org/10.2337/diabetes.51.4.1088

[101] Myśliwska, J., Zorena, K., Semetkowska-Jurkiewicz, E., Rachoń, D., Suchanek, H. and Myśliwski, A. (2005) High Levels of Circulating Interleukin-10 in Diabetic Nephropathy Patients. European Cytokine Network, 16, 117-122.

[102] Wong, C.K., Ho, A.W., Tong, P.C., Yeung, C.Y., Kong, A.P., Lun, S.W., Chan, J.C. and Lam, C.W. (2007) Aberrant Activation Profile of Cytokines and Mitogen-Activated Protein Kinases in Type 2 Diabetic Patients with Nephropathy. Clinical \& Experimental Immunology, 149, 123-131. http://dx.doi.org/10.1111/j.1365-2249.2007.03389.x

[103] Zamauskaite, A., Yaqoob, M.M., Madrigal, J.A. and Cohen, S.B. (1999) The Frequency of Th2 Type Cells Increases with Time on Peritoneal Dialysis in Patients with Diabetic Nephropathy. European Cytokine Network, 10, 219-226.

[104] Xu, X., Zheng, S., Yang, F., Shi, Y., Gu, Y., Chen, H., Zhang, M. and Yang, T. (2014) Increased Th22 Cells Are Independently Associated with Th17 Cells in Type 1 Diabetes. Endocrine, 46, 90-98. http://dx.doi.org/10.1007/s12020-013-0030-z

[105] Veldhoen, M., Uyttenhove, C., van Snick, J., Helmby, H., Westendorf, A., Buer, J., Martin, B., Wilhelm, C. and Stockinger, B. (2008) Transforming Growth Factor-Bold Beta "reprograms" the Differentiation of T Helper 2 Cells and Promotes an Interleukin 9-Producing Subset. Nature Immunology, 9, 1341-1346. http://dx.doi.org/10.1038/ni.1659

[106] Dardalhon, V., Awasthi, A., Kwon, H., Galileos, G., Gao, W., Sobel, R.A., Mitsdoerffer, M., Strom, T.B., Elyaman, W., Ho, I.C., Khoury, S., Oukka, M. and Kuchroo, V.K. (2008) IL-4 Inhibits TGF-Bold Beta-Induced Foxp $3^{+} \mathrm{T}$ Cells and, Together with TGF-Bold Beta, Generates IL-9 IL-10 $^{+}$Foxp3- Effector T Cells. Nature Immunology, 9, 1347-1355. http://dx.doi.org/10.1038/ni.1677

[107] Mantel, P.Y. and Schmidt-Weber, C.B. (2011) Transforming Growth Factor-Beta: Recent Advances on Its Role in Immune Tolerance. In: Cuturi, M.C. and Anegon, I., Eds., Suppression and Regulation of Immune Responses, Methods in Molecular Biology, Vol. 677, Humana Press, 303-338. http://dx.doi.org/10.1007/978-1-60761-869-0_21

[108] Beriou, G., Bradshaw, E.M., Lozano, E., Costantino, C.M., Hastings, W.D., Orban, T., Elyaman, W., Khoury, S.J., Kuchroo, V.K., Baecher-Allan, C. and Hafler, D.A. (2010) TGF-Beta Induces IL-9 Production from Human Th17 Cells. The Journal of Immunology, 185, 46-54. http://dx.doi.org/10.4049/jimmunol.1000356

[109] Vasanthakumar, R., Mohan, V., Anand, G., Deepa, M., Babu, S. and Aravindhan, V. (2015) Serum IL-9, IL-17, and TGF- $\beta$ Levels in Subjects with Diabetic Kidney Disease (CURES134). Cytokine, 72, 109-112. http://dx.doi.org/10.1016/j.cyto.2014.10.009

[110] Zhang, L., Li, Y.G., Li, Y.H., Qi, L., Liu, X.G., Yuan, C.Z., Hu, N.W., Ma, D.X., Li, Z.F., Yang, Q., Li, W. and Li, J.M. (2012) Increased Frequencies of Th22 Cells as Well as Th17 Cells in the Peripheral Blood of Patients with Ankylosing Spondylitis and Rheumatoid Arthritis. PLoS ONE, 7, e31000. http://dx.doi.org/10.1371/journal.pone.0031000

[111] Kagami, S., Rizzo, H.L., Lee, J.J., Koguchi, Y. and Blauvelt, A. (2010) Circulating Th17, 
Th22, and Th1 Cells Are Increased in Psoriasis. Journal of Investigative Dermatology, 130, 1373-1383. http://dx.doi.org/10.1038/jid.2009.399

[112] Ryba-Stanisławowska, M., Werner, P., Brandt, A., Myśliwiec, M. and Myśliwska, J. (2016) Th9 and Th22 Immune Response in Young Patients with Type 1 Diabetes. Immunologic Research, 64, 730-735. http://dx.doi.org/10.1007/s12026-015-8765-7

Submit or recommend next manuscript to SCIRP and we will provide best service for you:

Accepting pre-submission inquiries through Email, Facebook, LinkedIn, Twitter, etc. A wide selection of journals (inclusive of 9 subjects, more than 200 journals)

Providing 24-hour high-quality service

User-friendly online submission system

Fair and swift peer-review system

Efficient typesetting and proofreading procedure

Display of the result of downloads and visits, as well as the number of cited articles

Maximum dissemination of your research work

Submit your manuscript at: http://papersubmission.scirp.org/ 